865 boys have passed through it, 344 of whom have joined the army, navy, and colonial forces, and 241 have been provided with civil employment. These boys have almost universally turned out well, according to the characters that have been received of them. The education at the home is of a most practical character and well fitted to make them useful, law-abiding citizens. Officers of the public medical services will be glad to have learned recently from the Duke of York that in this Jubilee year of Her Majesty's sixty years' reign the Home is making progress. It is an institution that well deserves support, and it fulfils a very useful purpose and one that Gordon had most sincerely at heart.

\section{The Benin Despatches.}

Despatches from Admiral Rawson, Consul-General Moor, and others were published in the London Gazette of the 7th inst. Among the officers mentioned and specially commended by Admiral Rawson are the following: Fleet-Surgeon M. Fitzgerald, for having organised the medical department and rendered every assistance. Staff-Surgeons E. R. Dimsey, of the Phobe, and J. McC. Martin, of the Forte, were with the flying column, and upon them fell the whole work of attending the wounded and bringing them down. Surgeon R. T. A. Levinge, of the Alecto, is specially mentioned in Captain MacGill's despatch. Surgeon C. S. Facey, of the Widgeon, is mentioned in Captain O'Callaghan's despatch. Surgeon F. H. A. Clayton, of the St. George, although ill himself, worked most assiduously with the sick. Dr. R. D'Arcy Irvine, of the Niger Coast Protectorate, volunteered for, and was attached to, the Sapoba force; he was also most assiduous in his attention to the sick at Warrigi when there was no naval medical officer present.

Mobinisition of No. 5 Freld Hospital.

The Irish Times of the 21st inst. gives an account of the recent mobilisation of this field hospital at Island Bridge Barracks on the 19th inst. under the command of SurgeonLieatenant-Colonel Greene. Major-General Viscount Frankfort, in the absence of Lord Roberts, accompanied by several staff officers and Surgeon-Major-General Preston, Principal Medical Officer of Ireland, inspected the hospital, and expressed his warm approval of the highly satisfactory manner in which every detail was carried out. A hospital was prepared for the accommodation of 100 sick, with all necessary arrangements, in a very short space of time. The personnel of a field hospital consists of four medical officers, one quarter-master, one warrant officer, and thirty-nine noncommissioned officers and men. Provision is made for 100 sick, the Army Service Corps finding the waggons, \&c., necessary for transport.

The Benin Expedition Awards.

The Queen has given directions for the following appointment to the Most Distinguished Order of Saint Michael and Saint George in recognition of services rendered in connexion with the recent expedition to Benin:-To be Ordinary Member of the Third Class or Companion of the Most Distinguished Order: Fleet-Surgeon Michael Fitzgerald, Royal Navy. Her Majesty has also given orders for the following appointments to the Distinguished Service Order in recognition of the services of the undermentioned officers during the same expedition:-To be Companions of the Distinguished Service Order: Staff-Surgeon James McCardie Martin, Royal Navy; and Staff-Surgeon Edgar Ralph Dimsey, Royal Navy.

Th LATE Greco-TuRKish War.

According to the accounts which have appeared as to the medical arrangements of the Greek Army these do not appear to have betn at all satisfactory. There seems to have been an absence of organisation, and the sufferings of the sick and wounded, owing to the want of proper care, are stated to have betn considerable. Owing to the heavy rainfall to which the army was exposed at Domoko there was a large amount of sickness and the hospitals are crowded.

BELGAUM.

We learn by the last mail from India that cholera has been very prevalent of late in the villages to the south-east and south-west of B-lgaum, and that several cases have occurred in that city and the Sudder bazaar. There were also two fatal cases in the Last Yorkshire kegiment at that station.

Two new companies (Berkshire and Kent) have been added to the Militia Medical Sriaff Corpe. For commissions in these companies immediate apulication should be made to the ofticer commanding Militia Medical Sta:f Corps, Alderskot.

\section{Claterspondente.}

\author{
" Audi alteram partem."
}

\section{THE CALOMEL BATH.}

\section{To the Editors of TH $\mathrm{TANOET}$}

SiRs, - The first experiments with regard to the action of the calomel bath were made in a small room, the ir of which necessarily became impregnated with the vapour The result was that the action on the gums was quickly produced, and ten grains of calomel was generally sufficient to produce the required effect. In an ordinary room a drachm may be used to begin with. It is well that the calomel should be pure and not contain any free hydrochloric acid, which if breathed is apt to irritate the lungs. The presence of acid is readily ascertained by holding a piece of moistened litmus paper over the fumes. Messrs. Allen and Hanbury informed me that they kept the pure calomel. Mr. Lowe of Stafford-street was in the habit of having the calomel resublimed in order to get rid of any free acid which ordinary calomel generally contains. Mr. Lowe has also a box for administration of the calomel bath; with this apparatus very little of the calomel is breathed. The principal advantages of the administration of mercury by the calomel bath over some other modes of giving it are (1) it is clean and requires little exertion on the part of the patient, and (2) it does not irritate the digestive organs; but (3) by far the most important point is that it determines any action that may be taking place to the skin, and thereby prevents the affection of the internal organs. I can scarcely recall a case in which the treatment was commenced by the calomel bath and properly carried out in which the deeper structures were affected. In one case a patient, who had previously undergone a variety of treatment and had a hole in his hard palate before he commenced the treatment, did not recover. In this case nearly the whole of the outer table of the frontal bone perished The calomel bath has no influence upon the local or suppurating sore. With cleanliness this will heal without any specific treatment.

In the House of Lords recently Lord Lister mentioned that there was one matter which he did not like in the Act of 1866-viz., that when a woman was pronounced to be clear of disease she received a certificate which she was to carry about with her. This could be no real protection to others. It is true that after a patient has been affected with constitutional syphilis he is much less likely to take the disease again; but this does not apply to the local form of the disease-a patient supposed to be cured one day may be re-infected the next.

I am, Sirs, your obedient servant, HENRY LEE.

Queensborough-terrace, Hyde-park, W., May 19th, 1897.

\section{"THE QUESTION OF THE SECOND OVARY IN OVARIOTOMY:" To the Editors of THE LANCET.}

SIRS,--The diverse opinions expressed by the various writers on this question show how important it is to discuss temperately and without personal bias methods of procedure that may require re-consideration if performed under new conditions and in the light of greater experience. Aseptic surgery has so revolutionised all surgery that every operation requires to be re-considered in the light of the greater safety conferred upon it by antiseptic precautions, and no statistics are of the slightest value collected before this era, or, indeed, in the earlier imperfect stages of this period.

The question which I raised was whether the age of the patient might not be regarded as a determining factor where it was necessary to remupe one ovary, and the other was found in an early stage of simple cystic degeneration, not yet robbed of its function or likely soon to cause inconverierce. The plea was put fotward for a girl or young woman who might thus still be all. Wed the chance of becoming a motber, a natural inst nct which in many women-and I would say in the best women -is stro ger than the love of life itself. 'I bas this suggestion is con'r.ry to the practice hitherto generally 